\title{
ALEKSANDAR DEROKO'S WORK ON MEDIEVAL ARCHITECTURE AND ITS RELEVANCE TODAY
}

A $B$ S $S$ T $R$ R A C $C$

Meticulous record of more than 300 medieval structures, extensive fieldwork on numerous archeological sites, more than 100 texts and several critical books on medieval architecture mark professor Aleksandar Deroko's work on preserving medieval architectural heritage in Serbia and the former Yugoslavia. They are all aptly illustrated with his drawings and photographs. Deroko's genuine interest in medieval architecture and its preservation shaped his student days between the two world wars, a period also characterised by a clash between traditionalism and modernism in architecture. Destruction from war, public negligence of medieval heritage, the so-called "golden rush" when many hoped to uncover lost medieval treasures, and the overall lack of clear methodologies for the preservation of architectural heritage displeased young Deroko, who often publicly expressed his opinion on the urgent need for medieval structures to be saved and restored, and in particular religious architecture. Even his undergraduate thesis for his architectural degree, which focused on the Church of St. Sava in Belgrade, was inspired by medieval religious architecture and its values. This paper addresses the relevance of Deroko's work today, especially in the light of his understanding of medieval architecture as art and a dynamic cultural symbol relevant for architectural practices.
Jelena Bogdanović

Iowa State University

jelenab@iastate.edu
KEY WORDS

ALEKSANDAR DEROKO

PYOTR POKRYSHKIN

GABRIEL MILLET

HISTORIOGRAPHY

MEDIEVAL ARCHITECTURE

METHODOLOGY

WESTERN MEDIEVAL

BYZANTINE

SLAVIC ARCHITECTURE 
Everyone who has studied architecture at the University of Belgrade after the World War II (WWII) is familiar with Professor Aleksandar Deroko's (1894-1988) standard textbook Monumentalna i dekorativna arhitektura u srednjevekovnoj Srbiji (Monumental and Decorative Architecture in Medieval Serbia) ${ }^{1}$. The book was initially prepared for a course on Byzantine and ancient Serbian architecture, which Deroko taught since 1926, when he graduated and became a teaching assistant (Fig. 1), until his retirement as a full-time professor at the Faculty of Architecture in Belgrade. ${ }^{2}$ The book remains seminal work for various university courses on Byzantine and medieval architecture in Serbia and serves as undeniable evidence of his fulfilled, resourceful and highly successful academic career as a university professor and later a member of the Serbian Academy of Arts and Sciences. Written in Serbian language with an English summary, this highly legible book is accompanied by numerous photographs and delicate linear drawings, including a memorable book cover (Fig. 2) made by professor Deroko himself. Deroko acknowledged that his book borrowed methodological approach from earlier studies in architectural heritage in Serbia, and in particular from Pyotr Pokryshkin's (1870-1922) and Gabriel Millet's (1867-1953) books on Orthodox church architecture in Serbia. ${ }^{3}$

Indeed, the beginnings of scholarly studies of architectural heritage in Serbia are tied to the studies of architecture in the Balkans just before the World War I (WWI). Done by non-native intellectuals trained in various disciplines, these early studies were largely guided by political interests of major European powers at the time as well as by geographical and socio-political boundaries of the nation states in the Balkans. ${ }^{4}$ In the light of these circumstances, Pokryshkin's and Millet's scholary influence on Deroko's work can be found within a larger framework of studies in architectural heritage and its preservation across Europe, regardless of its political and social divides. ${ }^{5}$

The Russian architect, architectural historian and restorer, Pyotr Pokryshkin, was mostly interested in proper cataloguing and recording of architecture of the past in predominantly Eastern Orthodox Christian countries; a pioneering process which, at the time he began working on it, lagged behind a somewhat better developed studies of Western medieval architecture. Pokryshkin mostly catalogued and concerned himself with religious architecture of the Kingdom of Serbia between the twelfth and eighteenth centuries. For his book on medieval architecture, Deroko adopted this seemingly incorrect broad chronological span until the end of the seventeenth century for medieval arhictecture in his book on medieval architecture directly from Pokryshkin's book on the church architecture in Serbia. Yet, as Deroko himself explained, his decision can be 
justified by the conservative use and perseverance of medieval architectural styles for religious architecture in Serbian territories or in their former territories even under the Ottoman rule, which lasted well beyond the medieval period. ${ }^{6}$ Such a methodological framework applied to a very generous chronological span, but paradoxically being very coherent in investigations of church architecture in the Balkans, continues to be used in current sholarship. Most recently, the major publication on Serbian medieval art and architecture issued for the $23^{\text {rd }}$ International Congress of Byzantine Studies held in Belgrade, uses the same method to cover medieval religious art and their principles well until the end of the seventeenth century. ${ }^{7}$

The French archeologist and historian, Gabriel Millet, who is widely recognised as one of the major contributors to the revival of Byzantine studies in the late nineteenth and early twentieth centuries, made the most impact on Deroko (Fig. 3). Following successful completion of his undergraduate studies of architecture in Belgrade in 1926, Deroko studied with Millet at the École des hautes études in Paris thanks to a stipend from the French government. ${ }^{8}$ A pedant, Millet focused on the medieval period in accordance with major chronological divides for everything "medieval" as devised in Western thought. Yet, Millet also proposed and promoted the distinct "national schools" in the nation states of the Balkans, including Serbia, such as the "School of Raška," the "SerboByzantine school," and the "Morava school". 9 As a trained and practicing architect, Deroko correctly recognised difficulties in defining these specific architectural national "schools", which Millet offered as a working premise for studies of medieval architecture in the Balkans. ${ }^{10}$ In his texts, Deroko delicately substituted the term "schools" by "groups", thus opting for a clever compromise

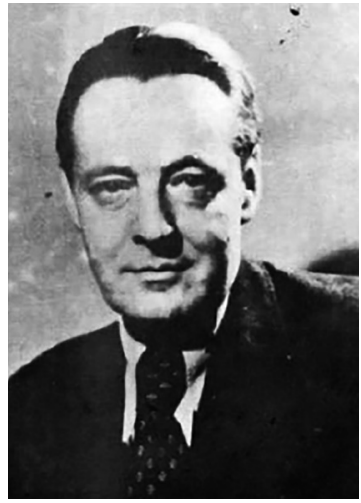

Fig. 1. Aleksandar Deroko upon graduating with a degree in architecture (archival photo)

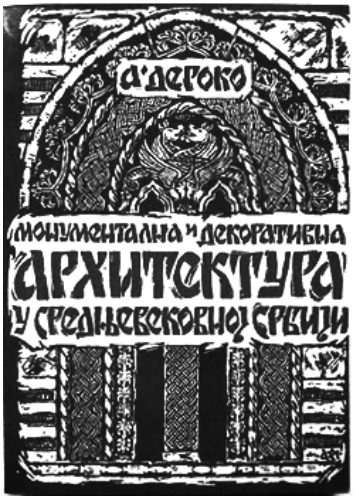

Fig. 2. Aleksandar Deroko, a book cover of Monumental and Decorative Architecture in Medieval Serbia

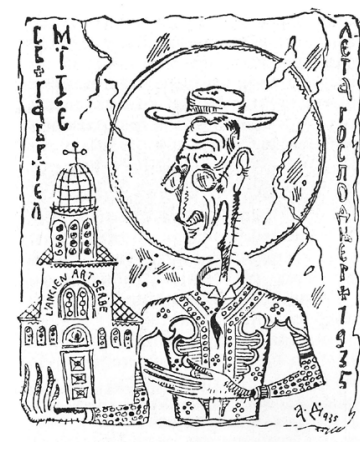

Fig. 3. Aleksandar Deroko, a drawing of Gabriel Millet, here inscribed as "St. Gabriel Millet" highlighting the respect Deroko held for Millet and his scholarship 
that still allowed for a wider contemporaneous intellectual discourse guided by its major proponents in the West. He explained his decision by saying that placing the architectural taxonomy into "groups" is just a methodological tool, which is definitely never absolute, accounts for fluidity of the exchange of architectural ideas and practices, and as medieval studies advance, remains open to modifications. ${ }^{11}$ By doing so, Deroko also favoured preserving the selected medieval as well as monumental objects that heavily relied on medieval traditions, predominantly churches, based on their territorial and chronological distribution, rather than on their unstable nation-based stylistic classification. These churches architecturally had clearly observable stylistic features in common, and occasionally the same patronage of their donors, who often belonged to the same family or larger socio-political groups (a ruling family, the aristocracy) within the changing territories of the state of Serbia and a wider network of architectural production sponsored by the Serbs. In contrast to Millet's Raška, Serbo-Byzantine, and Morava schools, which Millet defined as offspring of and relating to Byzantine architecture, Deroko recognised five, rather neutrally defined groups:

1. architecture in Zeta (modern Montenegro and parts of Croatia, including the related territories on the Adriatic Littoral) built roughly during the tenth and eleventh centuries;

2. architecture in Raška, medieval Kingdom of Serbia (also overlapping with the core of modern Serbia) during the twelfth and thirteenth centuries;

3. architecture in Kosovo and Metohija as well as in Macedonia as parts of medieval Serbia and sponsored by the Serbian patrons in the fourteenth century;

4. architecture in the independent Serbian principality of the Morava valley during the period of its existence (1371-1459); and

5. Serbian architecture in the former Serbian territories of Ottoman Empire, until the end of the seventeenth century.

Recently, scholars of medieval architecture in the Balkans have questioned its long-lasting but unstable historiographies largely based on national schools and their fragmented territorial claims, to which Deroko's work belongs only to an extent given his dealings with both Pokryshkin's and Millet's studies. ${ }^{12}$ At the most basic level, such historiographies definitely contribute to detailed and invaluable architectural studies in a given locale. Yet, by focusing exclusively on the architecture within the given state territory and by avoiding open analysis of the exchange of architectural ideas and practices that go well beyond the territorial and the socio-political claims, these studies of medieval architecture often remain marginalised in larger scholarly discussions. They occasionally 


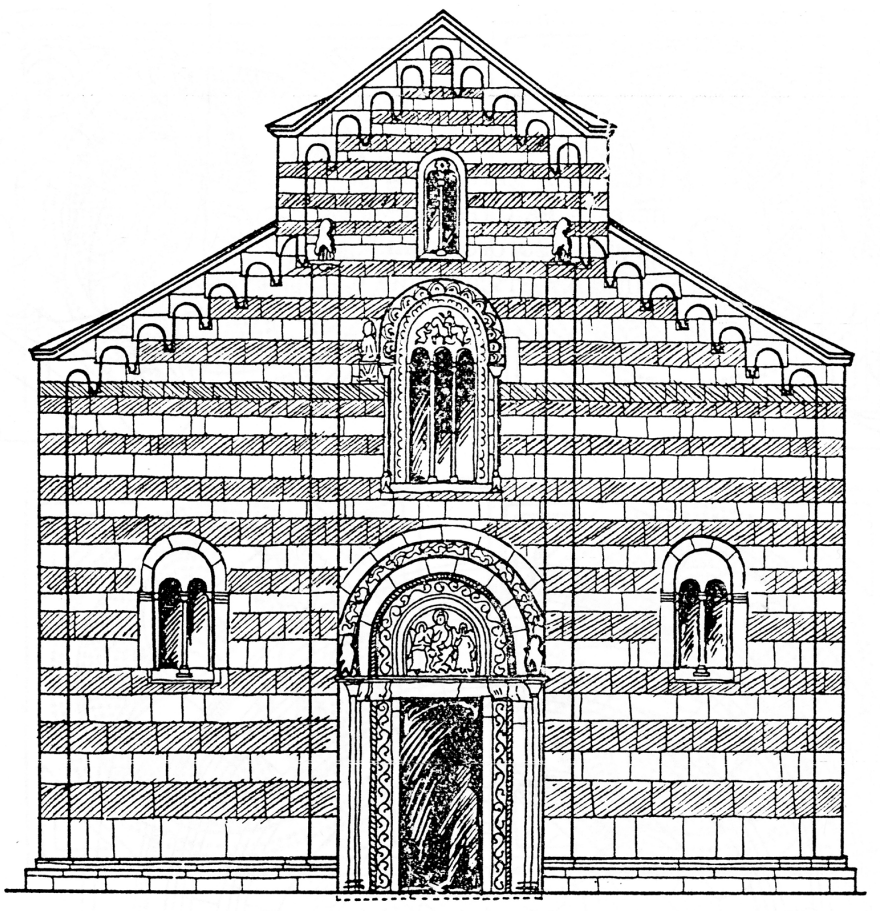

СЛ. 133 - ЗАПАДНА ФАСАДА ПРИПРАТЕ НА ЦРКВИ МАНАСТИРА ДЕЧАНА
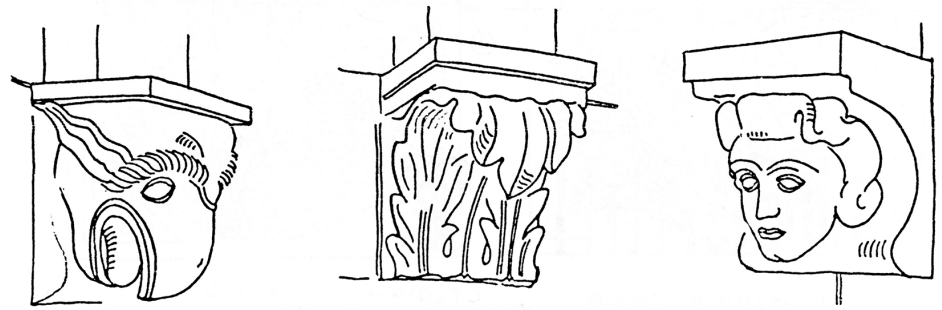

СЛ. 134 - КОНСОЛЕ ИСПОД АРКАДИЦА КРОВНОГА ВЕНЦА ЦРКВЕ МАНАСТІРА ДЕЧАНА.

Fig. 4. Aleksandar Deroko, architectural drawings of the façade and details of the Christ Pantokrator Church in Dečani Monastery (from Monumental and Decorative Architecture in Medieval Serbia, figs. 133 and 134 on p. 96). 
result in incomplete understanding of local traditions within major medieval architectural trends as well as the lack of complete appreciation of site-specific architectural heritage as common heritage of humanity. ${ }^{13}$

Needless to say, Deroko was well aware of these methodological issues and inconsistencies of any rigid and superficial grouping of architecture based on national, historical, geographical, and chronological premises. He wrote openly about these issues. Already in the introductory pages of his study on the monumental architecture in medieval Serbia, he emphasised that it is part of larger architectural developments, which Serbia shared with its neighbouring countries. ${ }^{14}$ He questioned its exclusive dependence on the Byzantine tradition only, and recurrently emphasised the multiple creative processes and trajectories in the articulation of unique architectural features of medieval architecture in Serbia. As a strong proponent of architecture used in scholarly discourse not merely as a subsidiary tool that supports socio-political historical narratives, Deroko highlighted the architectural criteria for devising specific architectural groups in medieval Serbia, which he neutrally numbered from one to five. ${ }^{15} \mathrm{By}$ focusing on architectural features themselves, Deroko reinforced understanding architecture as material evidence and an inseparable part of the material culture within a wider network of its production and reception. Therefore, Deroko's study on medieval architecture in Serbia is dominated by the following criteria: architectural typology, selection of building materials, specific solutions for singular architectural elements of larger edifices (walls, roofs, floors, interior furnishing) and their decoration, predominant function of selected religious structures, be it a monastery or a parish church, in case of monumental architecture (Fig. 4). ${ }^{16}$ These criteria are complemented by meticulous architectural analysis of the role of building practices, provenance and training of the builders, which can be occasionally revealed through textual sources, but more often through built structures themselves, and through analysing specific architectural concepts of space, structural solutions, the choice of measurement units, and monumental architectural decoration.

The specific value of Deroko's work, therefore, lies in his intellectually honest and genuine approach to architecture. Many of his more than 100 texts on medieval architecture have gained attention early on and a broader international scholarly community and the general public continue to consult these works. ${ }^{17}$ Deroko's work certainly remains open to modifications and further refinement as he himself recommended, but it continues to be recognised among scholars of medieval architecture today. Deroko's selection of major buildings and their architectural features presented in his 1950s textbook on monumental architecture in medieval Serbia is included and further elaborated in a major 
international authoritative text on medieval architecture in the Balkans written by Princeton University Professor Slobodan Ćurčić and published in 2010. ${ }^{18}$ The book is to date the most comprehensive work on medieval architecture in the Balkans. In his selective bibliography, Curčić also acknowledged Deroko's other relevant books on medieval towns and vernacular architecture in Serbia and the Balkans entitled Srednjevekovni gradovi u Srbiji, Crnoj Gori i Makedoniji (Medieval Towns in Serbia, Montenegro and Macedonia) and Narodno neimarstvo (Vernacular architecture) as still highly influential and reliable references. ${ }^{19}$

In addition to his study of monumental architecture, which is almost exclusively related to medieval religious architecture, Deroko simultaneously studied medieval towns and vernacular architecture; critical aspects of architecture that have only recently started to be given appropriate recognition and attention. Andrew Ballantyne not long ago summarised the essence of architecture, whether it is impressive in scale and its execution or not, monumental or vernacular, as being not simply the essence of buildings but rather that architecture is any building or built environment, with a significant cultural component. He wrote, "I want to argue that "architecture" is not the same thing as "good buildings" but is the cultural aspect of any building at all', and highlighted vernacular architecture, usually omitted from grand narratives on architecture, as a case in point. ${ }^{20}$ Deroko's early interest in towns and vernacular architecture was deeply rooted in his erudite understanding of architecture. As he wrote and illustrated in his works, despite being poorly preserved in the Balkans medieval castles, towns and vernacular architecture have a potential in reviving human conditions and life associated with the architecture of the past. Deroko never separated these investigations from material aspects and rigorous investigations of built architecture itself. Particularly instructing and accessible are his own

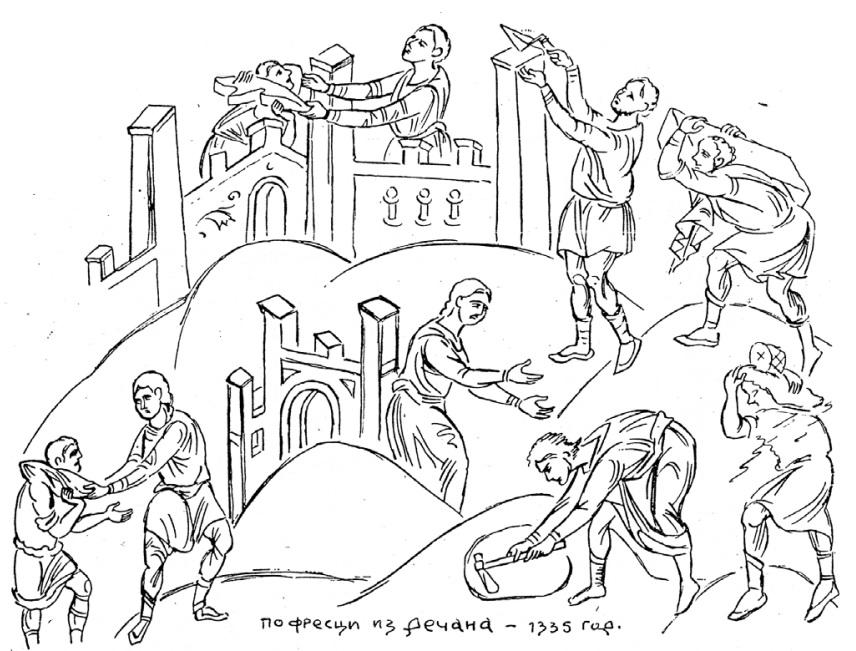

Fig. 5. Aleksandar Deroko, a linear drawing of the building of medieval town done after fourteenth-century fresco from Dečani Monastery (from Medieval Towns in Serbia, Montenegro and Macedonia, fig. 3) 
linear drawings, such as those that show a building of a medieval town or a celebration within it based on the fresco paintings from the fourteenth-century monastery of Dečani (Figs. 5 and 6). He carefully supplemented these images with contemporaneous textual sources and limited archeological evidence of actual medieval towns, their public spaces and residential architecture. Along with his professorial teaching and writing about medieval architecture, Deroko balanced his prolific academic work with extensive fieldwork. He actively participated in archeological work on major sites with clear urban and architectural stratification, including the famous sixth-century Justiniana Prima (Caričin Grad) built by Byzantine Emperor Justinian I in his native town near today's Lebane in southern Serbia, and Smederevo, the last capital city of medieval Serbia built by despot Djuradj Branković in the fifteenth century. ${ }^{21}$ Deroko's long-term interest in medieval secular architecture resulted in elegantly written, generously illustrated, and widely accessible books to both scholarly and non-academic audience. In addition to Srednjevekovni gradovi $u$ Srbiji, Crnoj Gori i Makedoniji and Narodno neimarstvo in two volumes Selo i Varoš (Village and Town), he also published Srednjevekovni gradovi na Dunavu (Medieval Castles on the Danube) and Srednjevekovni grad Skoplje (Medieval Town Skoplje, also in French Le Chaeteau fort médieval de Skoplje), the latter written in collaboration with Slobodan Nenadović and Vasa Čubrilović. ${ }^{22}$ His travels to Mt. Athos resulted in the book, Sveta Gora (Mt. Athos), which was also translated into English and published as Athos, The Holy Mountain, as well as in two texts on the Serbian Athonite monastery Hilandar entitled Iz materijalne prošlosti, etnografske beleške (From Cultural Past, Ethnographical Notes) and Konaci manastira Hilandar (Konaks of the Monastery Hilandar), the latter on monastic residential quarters which he co-authored with Professor Slobodan Nenadović. ${ }^{23}$ These seminal publications considered monastic architecture to be inseparable from its vernacular aspects and cultural values.

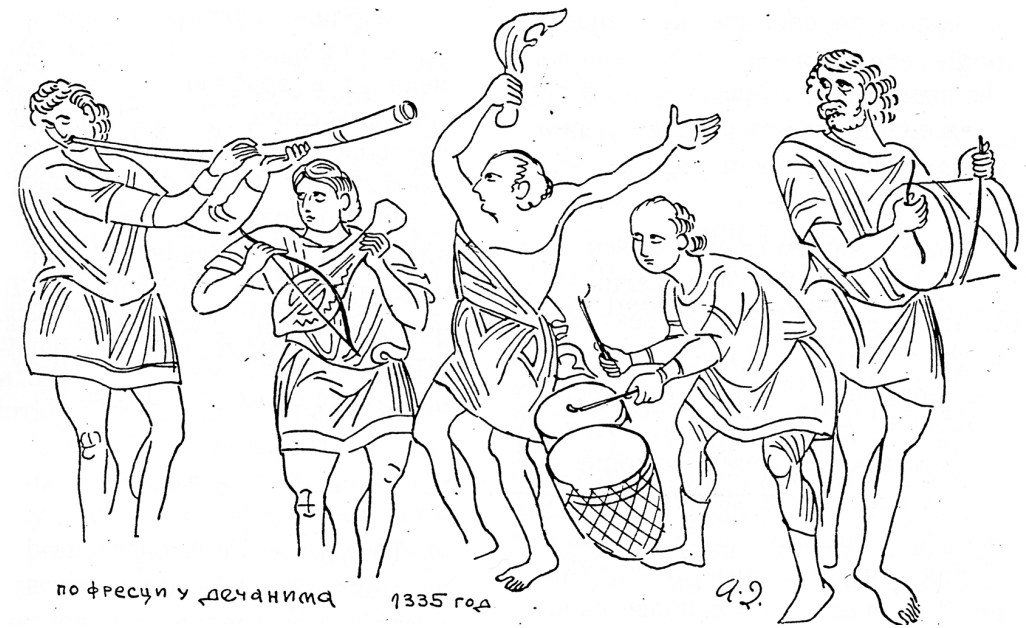

Fig. 6. Aleksandar Deroko, a linear drawing of the public life and entertainment in medieval times done after fourteenth-century fresco from Dečani Monastery (from Medieval Towns in Serbia, Montenegro and Macedonia, fig. 9) 


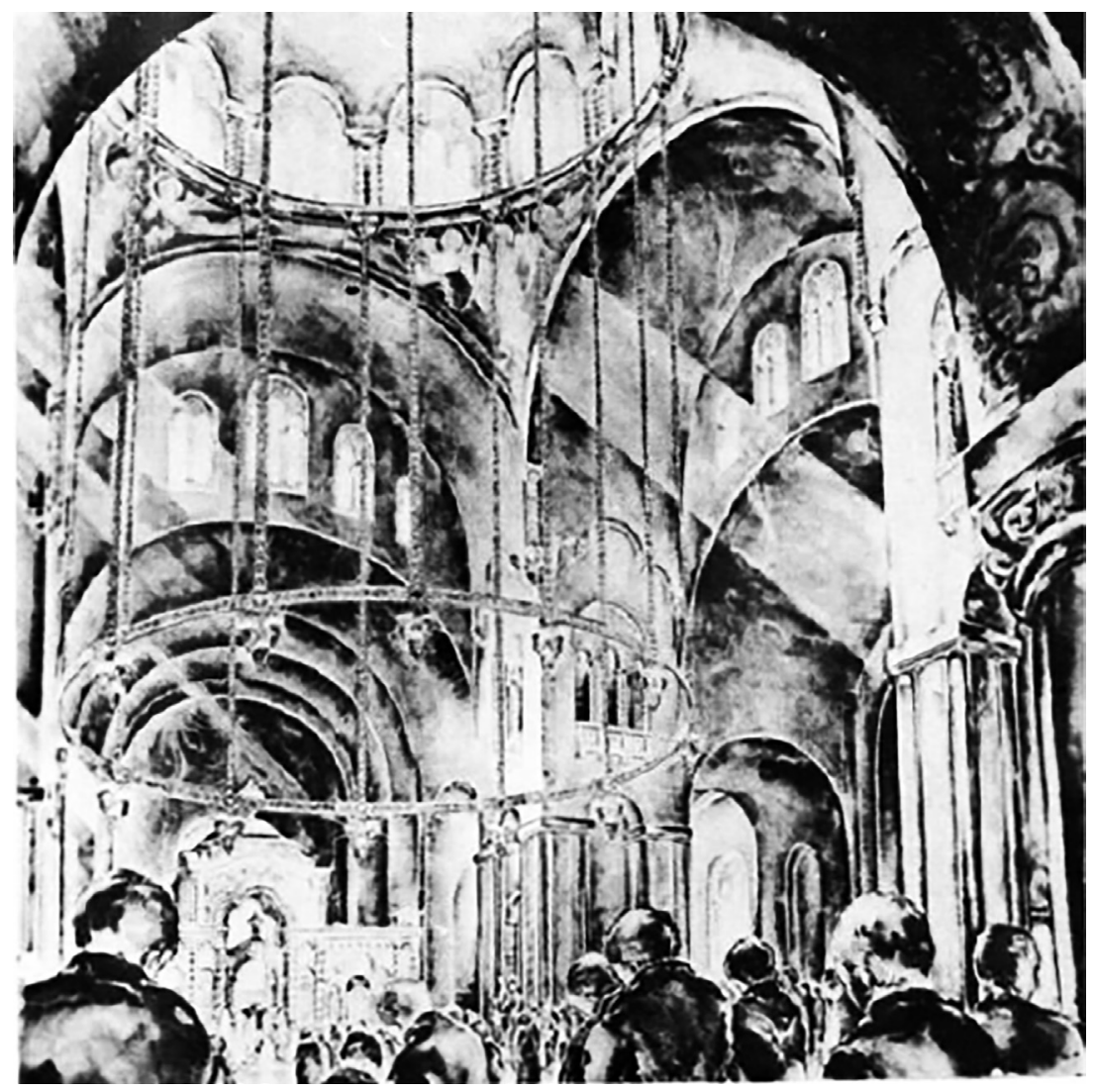

Fig. 7. Aleksandar Deroko, Interior of the Church of St. Sava in Belgrade, from the final exam for architectural degree. 
Even if personally deeply invested in this pioneering research on medieval vernacular architecture, which can be further attested to by his popular writings and witty and polemical pieces published in newspapers and dailies, Deroko's studies are always analytical, inclusive, non-speculative, detached from political jargon, and historically relevant. For example, already in his 1950s book on medieval towns Srednjevekovni gradovi u Srbiji, Crnoj Gori i Makedoniji (Medieval Towns in Serbia, Montenegro and Macedonia), Deroko recognised how in predominantly agricultural medieval territories of southwestern Balkans the concept of town was most often related to any type of fortification and walled enclosure it protected, including monasteries, and that the first architecturally fully recognisable medieval towns can be actually dated only to the late thirteenth and early fourteenth centuries. ${ }^{24}$ Lately, in their sophisticated studies of Serbian medieval towns based on the nuanced theoretical concepts of oekumene (polity, state) analysed through the application of the spatial syntax, or detailed analysis of the state apparatus, historical and archaeological evidence of urban life, scholars largely confirmed major premises of Deroko's early investigations of towns in medieval Serbia, which, despite being referenced to in earlier historic texts, can be traced only at the end of the thirteenth and at the beginning of the fourteenth centuries..$^{25}$

Deroko's solid and genuine understanding of medieval architecture in Serbia goes well beyond nationalistic and self-referential trends that were often framed by the political ideologies and academic curricula of nation states in the Balkans. Deroko subtly positioned his wide-ranging work and interest in medieval architecture and its preservation in the historical moment between traditionalism and modernism; the historical moment to which he belonged and in which he actively participated. He promoted the studies and preservation of medieval architecture as being complementary rather than in opposition to modernity. ${ }^{26}$ His earliest published text dating from 1922 is a magazine article on the monasteries in medieval Raška, which was then followed by 100 texts that disseminated knowledge about medieval architecture and more than 100 other texts that addressed Modernism and modernity in arts, architecture and culture. ${ }^{27}$ Deroko's final exam for his architectural degree in 1926 was the design for the Cathedral of St. Sava in Belgrade. ${ }^{28}$ With this design, he also participated in the competition for the conceptual design of the Church of St. Sava the same year. Deroko's project won the first monetary prize, which in 1932 secured him an opportunity to continue work on the project along with the winning architect Bogdan Nestorović. Deroko focused in particular on the church interior (Fig. 7). The competition rules that the design had to be within the Serbo-Byzantine style, whatever it meant in the early twentieth century, stirred a huge debate about traditionalism and modernism in architecture. Like 
in his texts on medieval architecture in Serbia, Deroko avoided oversimplified nationalistic framework and justified his design for the domed church interior by its dominant, monumental, and spiritual qualities that endured over time and became inseparable cultural dimension of the church building that serves Christian Orthodox, Byzantine rites. ${ }^{29}$

In 1927, Deroko followed and commented on the Second International Congress of Byzantine Studies held in Belgrade and published an article in Politika, the oldest daily in the Balkans, that put medieval artistic heritage of Serbia in focus of larger public discussions. ${ }^{30}$ His relentless work on the recognition of heavily decimated medieval architectural heritage as a common good was always framed by exacting request for the accurate preservation and protection of authentic remains. ${ }^{31}$ Only between 1925 and 1928, then young Deroko participated in archeological and conservation work of the monasteries of Žiča, Djurdjevi Stupovi in Budmilja, Djurdjevi Stupovi near Novi Pazar, Sopoćani, and Dečani. ${ }^{32}$ War destructions, general disinterest of public in medieval architectural heritage which resulted not only in negligence but also in its further devastation during the so-called "golden rush" when many amateur archeologists and treasure hunters searched for lost medieval treasures, and above all, the lack of clear scholarly methodologies, financial resources, and legal regulations for the preservation and conservation of medieval architectural heritage during the interwar period, deeply disturbed Deroko. He raised public awareness about the urgent need for medieval architecture to be saved and restored by actively participating in study travels to hundreds of archeological locations across Serbia and abroad, by arduously writing for academic and popular journals already as a student of architecture. ${ }^{33} \mathrm{He}$ also actively participated in the development of the studies of Byzantine and medieval architecture at the University of Belgrade. Within scholarly and public forums, he argued in favour of the best practices that would allow not only temporary conservation of medieval architecture but also its inclusion in contemporaneous public and cultural life. Deroko especially encouraged civic solutions for sophisticated incorporation of medieval architecture into contemporaneous urban and architectural texture. Such practices, he believed, would not only make old structures accessible to the wider public and use, but also emphasise the historical and aesthetical strata of architecture as a living heritage and presence. ${ }^{34}$ Yet, he recurrently made clear appeals for buildings that had been lost or severely devastated not to be reconstructed or rebuilt because limited material evidence prevents an accurate and professional historical reconstruction and presentation of architecture, which would then be presented without its original appearance and meaning. 
Deroko's understanding of medieval architecture as an art form and a dynamic cultural symbol remains relevant not only for architectural historiography but also for current architectural practice. Several themes emerge as exceptionally strong throughout his work: highly sophisticated comprehension of architecture beyond a mere structure; balance between poetical and technical aspects of architecture; the recognition of beauty as an immanent quality of architectural accomplishments, including medieval and vernacular; as well as almost avantgarde understanding of monumentality as an essential concept in architecture. Namely, Deroko's broad interest in urban developments and vernacular, non-monumental architecture along with representative monumental church architecture, reveal an independent intellectual who deeply knew architecture beyond its mere definition as a "shelter", beyond a "building", which is never devoid of its complex cultural, conceptual, and aesthetic references. His architectural vocation and training balanced between poiesis and techne, between immaterial and material aspects of architecture as art-making and craftsmanship, is further reflected in the acknowledgement of medieval architecture on multiple levels. Particularly revealing is Deroko's frequent recognition of the aesthetical values of medieval architecture and sensibility of its creators. In concluding remarks of his seminal book on monumental church architecture he elucidated its structural, architectural, and artistic values as embodiment of authentic medieval culture of the people who lived in the territories of medieval Serbia, Montenegro, and Macedonia. ${ }^{35}$ In his less known text entitled $O$ estetskom kriterijumu u starom našem neimarstvu (On the Aesthetic Criterion in Our Old Architecture), Deroko interpreted the architectural form of vernacular buildings as being articulated by the application of aesthetic criteria, in addition to the utilitarian, practical and structural considerations. ${ }^{36}$ As an architect and architectural historian, Deroko drew attention to architectural beauty that goes well beyond architectural ornament and interior wall decoration. His understanding of beauty of architecture additionally includes spatial concepts and architectural articulation of the façades. Monumentality itself is understood not only as an imposing scale and memorable quality of notable buildings. In Deroko's work, monumentality is continually an essential concept in architecture, an aesthetic criterion that often evokes spirituality and immaterial aspects of architecture, as well as an effective tool that shapes collective memory of various social and architectural groups. Professor Deroko's work on medieval architecture as well as its recognition of it as an art form and a dynamic cultural symbol, therefore, remains highly relevant not only for students of medieval architecture, architectural historians and conservators, but also for architects and their practices. 
NOTES

1

Aleksandar Deroko, Monumentalna i dekorativna arhitektura u srednjevekovnoj Srbiji [Monumental and Decorative Architecture in Medieval Serbia] (Belgrade: The Serbian Academy of Arts and Sciences, 1953, second edition 1962).

Zoran M. Jovanović, Aleksandar Deroko (Belgrade: Republički zavod za zaštitu spomenika kulture, 1991), 12 .

Petr Petrovič Pokriškin, Pravoslavnaia tserkovna arkhitektura XII-XVIII stol. Orthodox Church Architecture of the twelfth through to eighteenth centuries in the Kingdom of Serbia (St. Petersburg: publisher not identified, 1906). See also recent critical edition, Andjelija Polikarpova, Pravoslavna crkvena arhitektura XII-XVIII veka u Kraljevini Srbiji by P. P. Pokriškin. Orthodox Church Architecture of the $12^{\text {th }}-18^{\text {th }}$ centuries in the Kingdom of Serbia (Belgrade: Art Press, 2014). For Millet's critical study of Serbian architecture see, Gabriel Millet, L'ancien arte Serbe, Les Églises (Paris: E. de Boccard, 1919).

See, for example, Slobodan Ćurčić, Architecture in the Balkans from Diocletian to Süleyman the Magnificent (New Haven and London: Yale University Press, 2010), 8-10; Slobodan Ćurčić, "Architecture in Byzantium, Serbia and the Balkans Through the Lenses of Modern Historiography," in Serbia and Byzantium. Proceedings of the International Conference Held on 15 December 2008 at the University of Cologne, eds. M. Angar and C. Sode (Frankfurt am Main, Berlin, Bern, Bruxelles, New York, Oxford, Wien: Peter Lang, 2013), 9-31; Dubravka Preradović, "Contribution

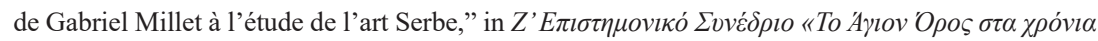

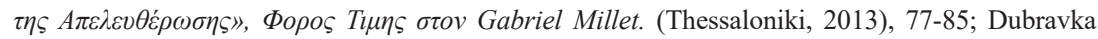
Preradović, "Le premier voyage de Gabriel Millet en Serbie et ses résultats," in Les Serbes à propos des Français - Les Français à propos des Serbes, eds. J. Novaković and Lj. P. Ristić (Belgrade: University of Belgrade, 2014), 187-205; Jelena Bogdanović, "The Preservation of Architectural Heritage after World War One: Mihajlo Pupin and His Book Serbian Orthodox Church," Zbornik Matice Srpske za Likovne Umetnosti 43 [Matica Srpska Journal for Fine Arts] (2015): 195-210.

On the complexities of the conservation movement and its historical developments see, for example, Miles Glendinning, The Conservation Movement. A History of Architectural Preservation Antiquity to Modernity (London and New York: Routledge, 2013), passim and especially "Part IV: 1945-89. Heyday of the Movement: Parallel narratives of postwar preservation,” 257-414.

Deroko, Monumentalna, 7, 19-22.

Sacral Art of the Serbian Lands in the Middle Ages, eds. Dragan Vojvodić and Danica Popović, vol. 2/3 of Byzantine Heritage and Serbian Art (Belgrade: The Serbian National Committee of Byzantine Studies, Službeni glasnik, Institute for Byzantine Studies, The Serbian Academy of Sciences and Arts, 2016).

Jovanović, Aleksandar Deroko, 13.

On the question of national schools of medieval architecture as formulated by Millet, see Ćurčić, Architecture in the Balkans, 8-10; Curčić, Architecture in Byzantium, Serbia and the Balkans, 9-31; Preradović, Contribution, 77-85; Preradović, Le premier voyage de Gabriel Millet, 187-205.

Deroko himself recorded and studied some 300 medieval structures supported by an extensive fieldwork. Information based on Jovanović, Aleksandar Deroko, 43.

Deroko, Monumentalna, 19-22, esp. 22.

Curčić, Architecture in the Balkans, 8-10. See also, Jelena Bogdanović, "Medieval Religious Architecture in the Balkans" in The Cambridge Guide to the Architecture of Christianity, eds. R. Etlin and A.-M. Yasin (Cambridge: Cambridge University Press, in press, scheduled for 2019).

Ćurčić, Architecture in the Balkans, 8-10; Bogdanović, The Preservation of Architectural Heritage, 195-210; Bogdanović, Medieval Religious Architecture in the Balkans (in press).

Deroko, Monumentalna, esp. 11-22; 262-263. 
Deroko, Monumentalna, esp. 7-22.

Deroko, Monumentalna, esp. 23-32.

For a detailed overview of Deroko's engagement with medieval architecture, both through field work and publications, see Jovanović, Aleksandar Deroko, 14, 21-33.

Ćurčić, Architecture in the Balkans, with acknowledgment of Deroko's seminal work on 17, 837, 884,889 .

Ćurčić, Architecture in the Balkans, with acknowledgment of Aleksandar Deroko's books, Srednjevekovni gradovi u Srbiji, Crnoj Gori i Makedoniji (Belgrade: Prosveta, 1950); Aleksandar Deroko, Narodno neimarstvo, vol. 1 (Belgrade: Srpska akademija nauka i umetnosti, 1968) on 891, 893.

See, for example, a fantastic summary on the limits of architectural studies in general that recurrently avoided studies of vernacular architecture in Andrew Balantyne, Architecture. A Very Short Introduction (Oxford: Oxford University Press, 2002), 24-32, citation on 31.

Jovanović, Aleksandar Deroko, 16.

Aleksandar Deroko, Karin Radovanović, Jan Dekker, Srednjevekovni gradovi na Dunavu [Medieval Castles on the Danube] (Belgrade: Turistička štampa, 1964), Aleksandar Deroko, Slobodan Nenadović, Vasa Čubrilović, Srednjevekovni grad Skoplje (Belgrade: Srpska akademija nauka i umetnosti, 1971).

Aleksandar Deroko, Sveta Gora (Belgrade: Narodna knjiga, 1967, third edition 1998); Aleksandar Deroko, Athos: The Holy Mountain (Belgrade: Turistička štampa, 1970); Aleksandar Deroko, Iz materijalne kulture prošlosti: etnografske beleške (Belgrade: Naučno delo, 1963) and Aleksandar Deroko, Slobodan Nenadović, "Konaci manastira Hilandar" Spomenik SANU CXX (Belgrade, 1971), 17-37. For detailed listing of Deroko's texts on medieval architecture, see also Jovanović, Aleksandar Deroko, 17, 21-33.

Deroko, Srednjevekovni gradovi, 9-24, esp. 10, 18-19.

Processes of Byzantinisation and Serbian Archeology, ed. Vesna Bikić, vol. 1/3 of Byzantine Heritage and Serbian Art (Belgrade: The Serbian National Committee of Byzantine Studies, Službeni glasnik, Institute for Byzantine Studies, Serbian Academy of Sciences and Arts, 2016); especially chapters by Mihailo St. Popović, "The 'Medieval Serbian Oecumene" - Fiction or Reality?" 37-44, Stanoje Bojanin and Bojana Krsmanović, "Byzantine Influence on Administration in the Time of the Nemanjić Dynasty", 45-52, and Marko Popović, "From the Roman Castel to the Serbian Medieval City", 53-66.

On the relationships between preservation and modernity across various geographies and times, see also, Mrinalini Rajagopalan, "Preservation and Modernity: Competing Perspectives, Contested Histories and the Question of Authenticity," in: The Sage Handbook of Architectural Theory (Los Angeles: SAGE, 2012), 308-325.

Aleksandar Deroko, “Tri manastira srednjevekovnog Rasa (Three Monasteries of Medieval Ras)," Misao X Belgrade (1922): 1673-1686. The full bibliographical list of Deroko's published works is provided by Jovanović, Aleksandar Deroko, 101-109.

Jovanović, Aleksandar Deroko, 64-67.

Jovanović, Aleksandar Deroko, 64-72, with detailed coverage on the polemics about the Cathedral of St. Sava in Belgrade and Deroko's participation within it.

Aleksandar Deroko, "Izložba naših vizantiskih umetničkih dela ("The Exhibition of our Byzantine art works")" Politika (April, 1927).

See, for example, Deroko, Srednjevekovni gradovi, 206.

Aleksandar Deroko, "Malo nekih davnih sećanja" Sećanja konzervatora (Some Distant Memories. Memories of the Conservator) (1982): 11-12. 
See, for example, Aleksandar Deroko, "Povodom jednog S.O.S. apela još od pre dvadeset godina (“On the occasion of one S.O.S. appeal from twenty years ago”)," Misao XII (1923): 838-842. On Deroko's meticulous record of medieval architecture and work on the development of policies for the preservation of architectural heritage in Serbia and former Yugoslavia, see also, Jovanović, Aleksandar Deroko, 41-49.

Deroko, Srednjevekovni gradovi, 206.

Deroko, Monumentalna, esp. 262-263.

Aleksandar Deroko, "O estetskom kriterijumu u starom našem neimarstvu" [On the aesthetic criterion in our old architecture] in XX vek (Belgrade, 1938), 13-17.

Bikić, Vesna ed. Processes of Byzantinisation and Serbian Archeology, vol. 1/3 of Byzantine Heritage and Serbian Art. Belgrade: The Serbian National Committee of Byzantine Studies, Službeni glasnik, Institute for Byzantine Studies, Serbian Academy of Sciences and Arts, 2016.

Bogdanović, Jelena. "Medieval Religious Architecture in the Balkans." In The Cambridge Guide to the Architecture of Christianity, edited by R. Etlin and A.-M. Yasin. Cambridge: Cambridge University Press, in press, scheduled for 2019.

Bogdanović, Jelena. "The Preservation of Architectural Heritage after World War One: Mihajlo Pupin and His Book Serbian Orthodox Church" Zbornik Matice Srpske za Likovne Umetnosti 43 [Matica Srpska Journal for Fine Arts] (2015), 195-210.

Ćurčić, Slobodan. "Architecture in Byzantium, Serbia and the Balkans Through the Lenses of Modern Historiography." In Serbia and Byzantium. Proceedings of the International Conference Held on 15 December 2008 at the University of Cologne, edited by M. Angar and C. Sode, 9-31. Frankfurt am Main, Berlin, Bern, Bruxelles, New York, Oxford, Wien: Peter Lang, 2013.

Ćurčić, Slobodan. Architecture in the Balkans from Diocletian to Süleyman the Magnificent. New Haven and London: Yale University Press, 2010. 
Deroko, Aleksandar, Karin Radovanović and Jan Dekker. Srednjevekovni gradovi na Dunavu [Medieval Castles on the Danube]. Belgrade: Turistička štampa, 1964.

Deroko, Aleksandar, Slobodan Nenadović. "Konaci manastira Hilandar." Spomenik SANU CXX (1971): 17-37.

Deroko, Aleksandar, Slobodan Nenadović, Vasa Čubrilović. Srednjevekovni grad Skoplje. Belgrade: Srpska akademija nauka i umetnosti, 1971.

Deroko, Aleksandar. "Izložba naših vizantiskih umetničkih dela" [The Exhibition of our Byzantine art works]. Politika (12 April. 1927).

Deroko, Aleksandar. "Malo nekih davnih sećanja." Sećanja konzervatora ["Some Distant Memories," Memories of the Conservator] (Belgrade, 1982): 11-12.

Deroko, Aleksandar. "O estetskom kriterijumu u starom našem neimarstvu" [On the aesthetic criterion in our old architecture]. XX vek (1938): 13-17.

Deroko, Aleksandar. "Povodom jednog S.O.S. apela još od pre dvadeset godina" [On the occasion of one S.O.S. appeal from twenty years ago]. Misao XII (1923): 838-842.

Deroko, Aleksandar. "Tri manastira srednjevekovnog Rasa" [Three Monasteries of Medieval Ras]. Misao X (1922): 1673-1686.

Deroko, Aleksandar. Athos: The Holy Mountain. Belgrade: Turistička štampa, 1970.

Deroko, Aleksandar. Iz materijalne kulture prošlosti: etnografske beleške. Belgrade: Naučno delo, 1963.

Deroko, Aleksandar. Monumentalna $i$ dekorativna arhitektura u srednjevekovnoj Srbiji [Monumental and Decorative Architecture in Medieval Serbia]. Belgrade: Serbian Academy of Arts and Sciences, 1953, second edition 1962.

Deroko, Aleksandar. Narodno neimarstvo, vols. 1 and 2 Varoš and Selo. Belgrade: Srpska akademija nauka i umetnosti, 1968.

Deroko, Aleksandar. Srednjevekovni gradovi u Srbiji, Crnoj Gori i Makedoniji [Medieval Towns in Serbia, Montenegro and Macedonia]. Belgrade: Prosveta, 1950.

Deroko, Aleksandar. Sveta Gora. Belgrade: Narodna knjiga, 1967, third edition 1998.

Glendinning, Miles. The Conservation Movement. A History of Architectural Preservation Antiquity to Modernity. London and New York: Routledge, 2013.

Jovanović, Zoran M. Aleksandar Deroko. Belgrade: Republički zavod za zaštitu spomenika kulture, 1991.

Millet, Gabriel. L'ancien arte Serbe, Les Églises. Paris: E. de Boccard, 1919.

Pokriškin, Petr Petrovič Pravoslavnaia tserkovna arkhitektura XII-XVIII stol. Orthodox Church Architecture of the 12th-18th centuries in the Kingdom of Serbia. St. Petersburg: publisher not identified, 1906.

Polikarpova, Andjelija. Pravoslavna crkvena arhitektura XII-XVIII veka u Kraljevini Srbiji by P. P. Pokriškin. Orthodox Church Architecture of the 12th-18th centuries in the Kingdom of Serbia. Belgrade: Art Press, 2014.

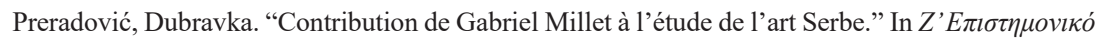

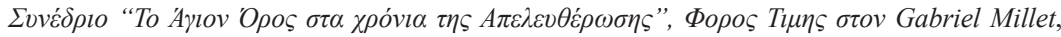
77-85. Thessaloniki, 2013.

Preradović, Dubravka. "Le premier voyage de Gabriel Millet en Serbie et ses résultats." In Les Serbes à propos des Français - Les Français à propos des Serbes, edited by J. Novaković and Lj. P. Ristić, 187-205. Belgrade: University of Belgrade, 2014.

Rajagopalan, Mrinalini. "Preservation and Modernity: Competing Perspectives, Contested Histories and the Question of Authenticity.” In The Sage Handbook of Architectural Theory, 308-325. Los Angeles: SAGE, 2012.

Vojvodić, Dragan and Danica Popović, eds. Sacral Art of the Serbian Lands in the Middle Ages, vol. 2/3 of Byzantine Heritage and Serbian Art. Belgrade: The Serbian National Committee of Byzantine Studies, Službeni glasnik, Institute for Byzantine Studies, Serbian Academy of Sciences and Arts, 2016. 